\title{
Faktor Lingkungan dan Perilaku Masyarakat Tentang Malaria di Kecamatan Kupang Timur Kabupaten Kupang
}

\section{Environment and Public Behaviour Factor about Malaria in East Kupang Subdistrict Kupang District}

\author{
Karolus Ngambut, Oktafianus Sila
}

\author{
Bidang Kajian Kesehatan Lingkungan Pusat Studi Kesehatan Poltekkes Kementerian Kesehatan Kupang
}

\begin{abstract}
Abstrak
Penelitian ini bertujuan untuk menggambarkan faktor lingkungan dan perilaku masyarakat tentang malaria di Kecamatan Kupang Timur Kabupaten Kupang. Dengan desain studi potong lintang, populasi penelitian adalah seluruh rumah tangga di Kecamatan Kupang Timur dengan metode simple random sampling dan diperoleh 185 rumah tangga yang dijadikan sampel. Hasil penelitian menunjukkan prevalens malaria klinis adalah $108(14,4 \%)$ pada satu tahun terakhir. Gambaran faktor lingkungan rumah penderita malaria yaitu dinding rumah terbuat dari bebak dan papan masing-masing $43,6 \%$ dan 7,9\%. Selain itu, atap rumah terbuat dari alangalang atau daun lontar $(21,1 \%)$. Sementara letak rumah dekat dengan breding places nyamuk anopheles, yaitu sawah dan lagoon sebanyak (84\%). Gambaran perilaku masyarakat dalam mencegah menceggah malaria menunjukkan 5,7\% masyarakat tidak melakukan apapun untuk melindungi diri dari gigitan nyamuk. Sebanyak $74,4 \%$ masyarakat kadang-kadang menggunakan kelambu. Dalam hal perilaku pencarian pengobatan, sebanyak 49\% masyarakat menggunakan obat tradisional, membeli obat di warung terdekat dan ada yang tidak melakukan apapun. Selain itu, sebagian besar penderita mencari pertolongan kepada tenaga kesehatan setelah lebih dari empat hari mendapat gejala. Disimpulkan bahwa kondisi fisik rumah dan lingkungan sekitar rumah serta perilaku berisiko masyarakat merupakan faktor determinan penting terjadinya terjadi malaria di wilayah Kabupaten Kupang. Disarankan upaya preventif dengan perbaikan lingkungan rumah dan promotif untuk perubahan perilaku perlu di perhatikan secara serius. Kata kunci : Kabupaten Kupang, lingkungan, malaria, perilaku
\end{abstract}

\section{Abstract}

The aims of this research was to identify the environment factors and the behavior factors related to the malaria in the. Using cross-sectional study design, the population was all households in the Kecamatan Kupang Timur Kabupaten Kupang. Used a simple random quota sampling method, the number of 185 households were as a respondents. The results showed the malaria prevalence was $108(14.4 \%)$ in the past year. The environment a condition which were consists of the homes of people with malaria were made of bebak and boards $43.6 \%$ and $7.9 \%$ respectively. Besides that, the Roofs house were made of palm leaves $(21.1 \%)$. The location of the respondent's house was close to the breeding places which is rice fields and lagoon are $155(84 \%)$. In terms of the community behavior in control malaria showed $5.7 \%$ of the community was not did anything to protect themselves from mosquito bites and $74.4 \%$ occasional community used mosquito nets have been distributed. Whereas in the case of treatment-seeking behavior shows $49 \%$ people used a traditional medicine, bought drugs at a nearby shop and there was not do anything. In addition, most of the malaria suferer looked after the health care after more than four days have symptoms. We concluded that the physical and the environment factors as well as behavior is an important determinant factors of malaria in Kupang. Recommended preventive efforts with environmental improvements to the house and promotif for behavior change is important.

Keywords: Kupang district, environment, malaria, behavior

\section{Pendahuluan}

Malaria adalah penyakit menular yang menjadi perhatian global. World Health Organization (WHO) memperkirakan tahun 2006 terdapat 247 juta kasus malaria dari 3,3 miliar penduduk yang berisiko, satu juta orang meninggal setiap tahun, lebih banyak pada usia bawah lima tahun. Kasus tersebut dilaporkan dari 109 negara di dunia dan 45 negara diantaranya terdapat di kawasan Afrika. ${ }^{1}$ Berdasarkan kategori tingkat endemisitas malaria, kawasan Afrika adalah daerah

Alamat Korespondensi: Karolus Ngambut, Bidang Kajian Kesehatan Lingkungan Pusat Studi Kesehatan Poltekkes Kemenkes Kupang, Jl. Piet A. Tallo, Liliba Kupang, NTT, Hp.081382682324, e-mail: karousng@yahoo.co.id 
endemis tinggi, kawasan Asia kategori moderat dan kawasan Amerika kategori endemis rendah terhadap Plasmodium falciparum. ${ }^{2}$ Selain itu, penduduk yang tinggal di daerah dengan berbagai tingkat risiko terhadap Plasmodium falciparum lebih banyak terdapat di kawasan Asia Tenggara (62,3\%), Afrika (27,7\%), Timur Tengah dan Eropa Timur (6,1\%), Amerika dan Karibia $(3,8 \%){ }^{3}$

Setiap tahun terdapat sekitar 15 juta kasus malaria dengan 38.000 kematian di Indonesia. Annual Malaria Incidence (AMI) secara nasional adalah 2,9\% dan tiga provinsi dengan AMI tinggi yaitu Papua Barat $(26,1 \%)$, Papua $(18,4 \%)$ dan NTT $(14,9 \%) .{ }^{4}$ Data AMI provinsi NTT menunjukan kecenderungan menurun selama enam tahun secara berturut-turut pada tahun 2003 hingga 2009 186\%o, 168\%o, 167\%o, 152\%o, $130 \%$, 92\%o, dan 74\%o. Namun, angka tersebut masih tetap tinggi di atas target nasional $(<50 \%)$. Annual Parasite Incidence (API) pada tahun 2007 hingga tahun 2009 sangat tinggi, yaitu tahun 2007 sebesar $32 \%$, tahun 2008 sebesar $28 \%$, dan tahun 2009 sebesar 31\%o, sedangkan rata-rata API Nasional $\left(<5 \%\right.$ o). ${ }^{5}$

Berbagai upaya telah dilakukan untuk menurunkan angka kesakitan dan kematian akibat malaria yang meliputi kegiatan penemuan dan pengobatan penderita, pemberantasan vektor dan upaya perlindungan diri terhadap gigitan nyamuk melalui pemakian kelambu berinsektisida. Upaya tersebut dilakukan oleh pemerintah di semua tingkatan adminisitrasi pelayanan kesehatan maupun oleh lembaga swadaya masyarakat (LSM) atau non-governmental organization (NGO) seperti German Technical Cooperation (GTZ), Australian Agency for International Development (AusAID), United Nations Children's Fund (UNICEF), dan Global Found. Dengan cara tersebut, kasus malaria di beberapa daerah dapat dikendalikan secara baik, namun di daerah lainnya termasuk di di Kabupaten Kupang hasilnya masih kurang memuaskan yang diindikasikan dengan masih tingginya angka AMI dan API selama beberapa tahun terakhir.

Penelitian ini bertujuan untuk mengidentifikasi faktor lingkungan dan perilaku masyarakat tentang penyakit malaria. Faktor lingkungan meliputi keadaan fauna di sekitar rumah, kondisi fisik rumah tempat tinggal, dan perilaku masyarakat yang berhubungan dengan malaria yaitu kebiasaan menggunakan kelambu, mencari pertolongan untuk berobat, kebiasan mengurangi gigitan nyamuk.

\section{Metode}

Penelitian ini merupakan jenis penelitian deskriptif dengan desain studi potong lintang. Penelitian ini dilakukan pada bulan Agustus sampai dengan bulan Oktober tahun 2011. Variabel dalam penelitian ini terdiri dari faktor lingkungan dan perilaku. Data dikumpulkan melalui observasi terhadap faktor lingkungan dan wawancara pada subjek penelitian tentang malaria. Populasi penelitian adalah seluruh rumah tangga yang ada Kecamatan Kupang Timur Kabupaten Kupang NTT yang merupakan merupakan daerah endemis tinggi malaria di Kecamatan Kupang Timur. Metode sampling adalah simple random sampling. Kriteria inklusi sampel dalam penelitian ini yaitu rumah tangga yang berada di wilayah Kecamatan Kupang Timur, kepala rumah tangga atau anggota rumah tangga yang berusia 18 tahun atau lebih, bersedia untuk di wawancarai dengan menandatangani informed consent. Kriteria eksklusi penelitian ini adalah tidak di jumpai anggota rumah tangga yang di kunjungi saat survei dilakukan, rumah tangga tidak termasuk dalam wilayah penelitian dan tidak bersedia untuk dijadikan responden penelitian.

Data kondisi lingkungan yaitu jenis dinding, langitlangit, dan keberadaan tempat perindukan vektor nyamuk diamati dengan berpedoman pada lembar observasi. Data perilaku masyarakat yaitu kebiasaan menggunakan kelambu, kebiasaan menggunakan obat anti malaria diperoleh melalui wawancara terhadap subjek penelitian dengan menggunakan instrumen yang telah dipersiapkan. Wawancara dilakukan terhadap kepala keluarga. Jika kepala keluarga berhalangan, maka digantikan oleh orang dewasa yang berusia 18 tahun atau lebih. Pengumpulan data dilapangan dilakukan oleh peneliti dan dibantu oleh enam orang mahasiswa Jurusan Kesehatan Lingkungan Politeknik Kesehatan Kementerian Kesehatan Kupang selama satu minggu. Keenam orang mahasiswa tersebut dilatih terlebih dahulu tentang teknik melakukan wawancara dan cara menggunakan instrumen penelitian. Persiapan selama dua hari, hari pertama bertujuan memahami garis besar penelitian dan instrumen yang akan digunakan, dan hari kedua uji coba melakukan wawancara.

\section{Hasil}

Karakteristik Responden

Jumlah responden yang diwawancara sama dengan jumlah rumah yang disurvei yaitu sebanyak 185 orang dan total jumlah jiwa dalam seluruh rumah tangga berjumlah 749 jiwa. Setiap rumah tangga terdiri dari tiga sampai lima orang dengan rata-rata 4 orang tiap rumah tangga. Responden tersebut terdiri dari 122 orang $(66 \%)$ laki-laki. Pada umumnya kepala keluarga yaitu 78 orang $(63,6 \%)$ dan $18,6 \%$ wawancara dilakukan terhadap wakil dari keluarga yaitu anak-anak yang berusia 18 tahun ke atas. Tingkat pendidikan responden bervariasi, terbanyak tamat SD dan SMA yaitu masing-masing $36,7 \%$ dan $28,1 \%$. Jenis pekerjaan yang ditekuni sebagai mata pencaharian utama adalah bertani dan pedagang kecil masing-masing $57,9 \%$ dan 
Tabel 1. Karakteristik Responden Penelitian di Kecamatan Kupang Timur Tahun 2011

\begin{tabular}{llll}
\hline Karakteristik Responden & Kategori & n & Persentase (\%) \\
\hline Jenis kelamin & Laki-laki & 122 & 65,7 \\
Kedudukan dalam rumah tangga & Perempuan & 63 & 34,3 \\
& Kepala keluarga & 78 & 42 \\
& Istri/ibu rumah tangga & 34 & 18 \\
Usia (tahun) & Anak & 44 & 24 \\
& $25-30$ & 46 & 25,0 \\
& $31-40$ & 90 & 48,5 \\
Pendidikan terakhir & $41-45$ & 33 & 17,8 \\
& >45 & 16 & 8,5 \\
& Tidak tamat SD & 15 & 8,0 \\
& Tamat SD & 68 & 36,7 \\
& Tamat SMP & 46 & 24,8 \\
& Tamat SMA & 52 & 28,1 \\
Pekerjaan & Tamat PT & 3 & 1,6 \\
& Kursus informal & 1 & 0,5 \\
& Tidak bekerja & 3 & 1,4 \\
& Bertani & 107 & 57,9 \\
& Buruh tani & 3 & 1,4 \\
& Pedagang kecil & 40 & 21,4 \\
& PNS & 4 & 2,1 \\
& Ibu rumah tangga & 17 & 9,3 \\
& Pensiunan & 1 & 0,7 \\
& Pekerja profesional & 1 & 0,7 \\
& Tukang ojek & 9 & 5,0 \\
\hline
\end{tabular}

Tabel 2. Keadaan Lingkungan dan Bangunan Rumah Responden di Kecamatan Kupang Timur Tahun 2011

\begin{tabular}{lllc}
\hline Variabel & Kategori & $\mathbf{n}$ & Persentase (\%) \\
\hline \multirow{2}{*}{ Jenis dinding rumah } & Tembok/beton & 83 & 45,0 \\
& Papan/seng & 15 & 7,9 \\
& Bebak & 81 & 43,6 \\
& Daun-daunan & 7 & 3,6 \\
Jenis atap & Seng & 146 & 78,9 \\
& Daun-daunan & 39 & 21,1 \\
Jarak rumah dengan tempat perindukan & $<200$ meter & 155 & 84,0 \\
& $>200$ meter & 30 & 16,0 \\
\hline
\end{tabular}

21,4\%. Dari 749 jiwa jumlah anggota keluarga, sebanyak 108 orang $(14,4 \%)$ diantaranya pernah menderita malaria dalam satu tahun terakhir (bulan Juli 2010 hingga bulan Juli 2011). Dengan kata lain, rata-rata setiap rumah tangga dilaporkan pernah menderita malaria dalam satu tahun terakhir. Penderita malaria tersebut lebih sebagian besar adalah laki-laki $(57,8 \%)$ dan $26 \%$ adalah usia balita. Selain itu, sebanyak $53,0 \%$ pendidikan penderita tidak sekolah dan sampai tamat SD tetapi terdapat $6,7 \%$ berpendidikan tinggi (Tabel 1).

\section{Faktor Lingkungan}

Kondisi rumah tempat tinggal terbanyak adalah rumah berdinding tembok (45\%) dengan jenis atap rumah yang paling dominan adalah rumah yang beratap seng $(78,9 \%)$ dan atap daun-daunan alang-alang atau daun lontar $21,1 \%$. Selain itu, keadaan lingkungan rumah tempat tinggal responden yang dikelom- pokkan berdasarkan pada ada atau tidaknya tempat perindukan nyamuk berupa genangan air dan parit atau sawah dan kolam serta semak-semak pada jarak kurang lebih 200 meter dari tempat rumah tempat tinggal sesuai dengan jarak terbang maksimal dari nyamuk.6,7 Hasil survei menunjukkan pada umumnya $(84 \%)$ atau 155 rumah responden dekat dengan daerah persawahan yang sangat potensial menjadi tempat berkembangbiaknya nyamuk/vektor malaria, sedangkan yang lainnya berada pada jarak lebih dari 200 meter dari tempat perindukan (Tabel 2).

\section{Faktor Perilaku}

\section{Pengetahuan Responden Tentang Malaria}

Tabel 3 menunjukkan sebagian besar (96\%) responden pernah mendengar penyakit malaria, sedangkan 4\% lainnya lainnya tidak dapat menjawab pertanyaan. Mereka pada umumnya belum tamat SD ke bawah. Pengetahuan responden ten- 
tang akibat dari penyakit malaria menunjukkan bahwa $17,6 \%$ responden mangatakan bahwa malaria tidak dapat membunuh jika tidak diobati. Selain itu, 22\% responden mengetahui bahwa malaria bisa kambuh dan $4 \%$ dari responden juga mengungkapkan malaria tidak dapat mengganggu pekerjaan mereka sehari-hari. Sebanyak $62,8 \%$ responden belum mengetahui gejala malaria secara pasti, ada yang mengatakan pedis ulu hati $(8,6 \%)$, kurang energi dan muntah masing-masing $13,5 \%$ dan $5 \%$. Selain itu, masih ada yang tidak tau tentang gejala malaria $(12,1 \%)$, serta $1,4 \%$ responden tidak memberikan jawaban terhadap pertanyaan tersebut. Responden ini kebanyakan adalah petani dan tingkat pendidikan umumnya belum tamat SD. Dalam hal sumber informasi tentang malaria, paling banyak diperoleh media di fasilitas kesehatan dan penyuluhan yang dilakukan oleh tenaga kesehatan yaitu 88 orang dari 178 orang responden $(49,3 \%)$, dari selebaran atau poster $20 \%$. Sedangkan informasi dari teman 3,6\%. Dalam hal jenis informasi yang diinginkan, responden paling banyak menginginkan informasi tentang cara pengobatan, kemudian diikuti oleh informasi tentang cara pencegahan malaraia serta informasi umum tentang malaria yaitu masing-masing $34,3 \%$ dan $22,1 \%$. Hanya $6,4 \%$ responden menginginkan informasi mengnenai perjalanan penyakit malaria.

\section{Perilaku Pencarian Pengobatan}

Pada Tabel 4 menunjukkan terdapat 121 orang dari 178 orang responden yang dalam satu tahun terakhir pernah menderita malaria menunjukkan perilaku yang berbeda-beda dalam hal pencarian pengobatan. Hasil penelitian menunjukkan bahwa pada saat mendapatkan gejala malaria umumnya membeli obat di kioskios atau ke toko obat terdekat $(78,6 \%)$ terlebih dahulu kemudian ke fasilitas kesehatan kalau belum sembuh, sedangkan $21,4 \%$ langsung ke fasilitas kesehatan. Namun, masih ada yang menggunakan obat tradisional yaitu sebanyak $16,4 \%$. Pada umumnya, mereka adalah perempuan dan berpendidikan tidak tamat

Tabel 3. Pengetahuan Responden Tentang Malaria di Kecamatan Kupang Timur

\begin{tabular}{llll}
\hline Variabel & Kategori & $\mathbf{n}$ & $\mathbf{( \% )}$ \\
\hline Pernah mendengar malaria $(\mathrm{n}=185)$ & Ya & 178 & 96 \\
& Tidak & 0 & 0 \\
& Tidak menjawab & 7 & 4 \\
Anggota keluarga menderita malaria & Ya & 108 & 14,4 \\
dalam satu tahun belakangan $(\mathrm{n}=749)$ & Tidak & 641 & 85,6 \\
Apa yang menularkan malaria $(\mathrm{n}=185)$ & Nyamuk & 159 & 86,0 \\
& Tidak tahu & 26 & 14,0 \\
Malaria bisa membunuh jika tidak & Ya & 153 & 82,6 \\
diobati (n = 185) & Tidak & 23 & 12,5 \\
& Tidak tahu & 9 & 5,1 \\
Malaria bisa kambuh $(\mathrm{n}=185)$ & Ya & 59 & 32 \\
& Tidak & 85 & 46 \\
Malaria bisa mengganggu pekerjaan & Tidak tahu & 41 & 22 \\
(n=185) & Ya & 178 & 96 \\
Gejala malaria $(\mathrm{n}=140)$ & Tidak & 7 & 4 \\
& Sakit kepala & 25 & 17,9 \\
& Panas/demam & 27 & 19,3 \\
& Badan sakit & 31 & 22,1 \\
& Pedis ulu hati & 12 & 8,6 \\
& Muntah & 7 & 5 \\
& Kurang energi & 19 & 13,6 \\
& Tidak tahu & 17 & 12,1 \\
& Tidak menjawab & 2 & 1,4 \\
\hline
\end{tabular}

Tabel 4. Sumber Informasi Tentang Malaria di Kecamatan Kupang Timur

\begin{tabular}{llll}
\hline Variabel & Kategori & $\mathbf{n}$ & $\mathbf{( \% )}$ \\
\hline Sumber informasi & Teman & 6 & 3,6 \\
& Anggota keluarga & 20 & 11,4 \\
& Selebaran/poster & 36 & 20,0 \\
& Radio & 27 & 15,0 \\
& Fasilitas kesehatan & 88 & 49,3 \\
& Tidak ada jawaban & 1 & 0,7 \\
Informasi yang diinginkan & Tentang pengobatannya & 61 & 34,3 \\
& Pencegahan penyakit & 47 & 26,4 \\
& Perjalanan penyakit & 11 & 6,4 \\
& Informasi apa saja tentang malaria & 39 & 22,1 \\
& Tanda dan gejala & 17 & 9,3 \\
Tempat mencari pengobatan & Tidak tahu & 4 & 2,1 \\
& Fasilitas kesehatan & 51 & 28,6 \\
& Obat tradisional/dukun & 29 & 16,4 \\
& Toko obat/apotik & 140 & 78,6 \\
& Tidak kemana-mana & 25 & 14,3 \\
Lama waktu mencari pertolongan ke & Tidak tahu & 4 & 2,1 \\
fasilitas kesehatan & Dalam hari itu juga & 6 & 3,6 \\
& Dua-tiga hari kemudian & 76 & 42,9 \\
& Empat-enam hari kemudian & 81 & 45,7 \\
& Lebih dari enam hari & 9 & 5 \\
& Tidak ada jawaban & 5 & 2,9 \\
\hline
\end{tabular}


Tabel 5. Upaya Responden Terhadap Gigitan Nyamuk di Kecamatan Kupang Timur

\begin{tabular}{|c|c|c|c|}
\hline Variabel & Kategori & $\mathbf{n}$ & $(\%)$ \\
\hline \multirow[t]{5}{*}{ Perlindungan Individu } & Menggunakan obat penolak seperti autan & 27 & 15,2 \\
\hline & Menggunakan obat nyamuk bakar & 81 & 45,5 \\
\hline & Membakar daun & 34 & 19,3 \\
\hline & Menutup pintu dan jendela & 25 & 14,3 \\
\hline & Tidak berbuat apa-apa & 10 & 5,7 \\
\hline \multirow[t]{2}{*}{ Malaria bisa dicegah } & Ya & 118 & 66,4 \\
\hline & Tidak & 60 & 33,6 \\
\hline \multirow{2}{*}{ Kepemilikan kelambu dalam rumah } & Ada kelambu & 164 & 92,1 \\
\hline & Tidak ada kelambu & 14 & 7,9 \\
\hline \multirow[t]{2}{*}{ Frekuensi penggunaan kelambu saat tidur } & Selalu digunakan & 46 & 25,6 \\
\hline & Kadang-kadang & 132 & 74,4 \\
\hline \multirow[t]{5}{*}{ Angggota keluarga yang tidur dalam kelambu } & Ayah & 24 & 17,1 \\
\hline & Ibu & 63 & 45,0 \\
\hline & Anak-anak $<$ lima tahun & 25 & 17,9 \\
\hline & Anak-anak > lima tahun & 17 & 12,1 \\
\hline & Tidak ada jawaban & 11 & 7,9 \\
\hline
\end{tabular}

Tabel 6. Pengetahuan Responden Tentang Vektor Malaria di Kecamatan Kupang Timur

\begin{tabular}{llll}
\hline Variabel & Kategori & n & $(\%)$ \\
\hline Waktu menggigit nyamuk & Pagi & 13 & 7,1 \\
& Siang & 15 & 8,6 \\
& Sore & 66 & 37,1 \\
& Malam & 84 & 47,1 \\
Tempat nyamuk menggigit & Dalam rumah & 107 & 60,0 \\
& Luar rumah & 71 & 40,0 \\
Tempat berkembang biak jentik nyamuk & Di parit/genangan air & 109 & 61,4 \\
& Di semak-semak & 62 & 35,0 \\
& Tidak tahu & 11 & 6,4 \\
Cara mengurangi gigitan nyamuk & Membersihkan lingkungan & 65 & 36,4 \\
& Membakar dedauan & 113 & 63,6 \\
\hline & & & \\
\hline
\end{tabular}

SD tetapi hanya lima orang yang berpendidikan tamat SMU. Dalam hal mencari pertolongan ke fasilitas kesehatan, kebanyakan responden mencari pertolongan ke fasilitas kesehatan setelah $4-6$ hari mendapatkan gejala sakit malaria seperti deman, panas dan menggigil yaitu 45,7\% dan kemudian 2 - 3 hari kemudian yaitu $42,9 \%$, dan bahkan ada juga setelah seminggu atau lebih mendapatkan gejala sakit $(5 \%)$. Hanya $3,6 \%$ saja responden yang mendapatkan gejala sakit malaria yang langsung mendatangi fasilitas kesehatan untuk mendapatkan pertolongan oleh tenaga kesehatan.

\section{Perilaku Mencegah Gigitan Nyamuk}

Perilaku responden untuk mencegah gigitan nyamuk terdiri dari beragam cara. Paling banyak menggunakan obat nyamuk bakar $(45,5 \%)$ kemudian membakar dedaunan pada malam hari $(19,3 \%)$ dan menggunakan obat penolak seperti autan sebanyak $(15,2 \%)$. Namun demikian, masih ada rumah tangga yang tidak berbuat sesuatu untuk mencegah terjadinya gigitan nyamuk, $(5,7 \%)$. Dalam hal penggunaan ke- lambu, terdapat 92,1\% rumah tagga yang memiliki kelambu di rumahnya. Kelambu-kelambu tersebut ada yang di beli sendiri dan ada yang dibagi dari petugas kesehatan pada satu tahun terakhir. Dalam hal penggunaan kelambu, sebagian besar responden $(74,4 \%)$ menggunakan kelambu kadang-kadang saja pada saat tidur. Ibu-ibu paling dominan tidur dalam kelambu (445\%), anak-anak berusia kurang dari 5 tahun $(17,5 \%)$ dan ayah mereka juga tidur dalam kelambu $(17,1 \%)$, terdapat juga anak-anak yang berusia lebih dari lima tahun juga yang tidur dalam kelambu $(12,1 \%)$ (Tabel 5).

\section{Pengetahuan Tentang Vektor Malaria}

Tabel 6 menunjukkan sebagian besar $(86,0 \%)$ responden mengetahui bahwa nyamuk adalah vektor yang menularkan malaria. Sebanyak $47 \%$ responden menyatakan nyamuk malaria menggigit pada malam hari dan $37,1 \%$ mengatakan nyamuk menggigit pada sore hari. Selain itu, $8,6 \%$ dan $7,1 \%$ responden juga menyatakan bahwa nyamuk penular malaria menggigit manusia pada siang dan pagi hari. Selain itu, 60 res- 
ponden mengatakan nyamuk hanya menggigit di dalam rumah dan $40 \%$ lainnya mengatakan nyamuk hanya mengigit di luar rumah. Pengetahuan responden tentang tempat berkembangbiaknya jentik nyamuk menunjukkan bahwa 49\% mengatakan jentik nyamuk berkembang biak di parit-parit atau di genangan air, $35 \%$ menyatakan jentik nyamuk berkembang biak di semak-semak, 6,4\% menjawab tidak tahu tentang tempat berkembangbiaknya jentik nyamuk. Mereka ini yang menjawab tidak tahu adalah 7 orang perempuan dan 2 orang laki-laki serta berpendidikan SD dan SMP. Terkait dengan cara untuk mengurangi gigitan nyamuk, sebagian besar responden $(63,6 \%)$ mengatakan untuk mengusir nyamuk dilakukan dengan cara membakar dedaunan di sekitar rumah dan melakukan kegiatan pembersihan lingkungan $(36,4 \%)$.

\section{Pembahasan}

Sebanyak 96\% responden pernah mendengar tentang malaria, selain itu dalam satu tahun terakhir 14,4\% masyarakat pernah di diagnosa malaria oleh petugas kesehatan. Hasil penelitian ini sangat berbeda dengan angka insidens malaria di NTT. Besarnya prevalensi malaria tersebut jauh lebih kecil $(0,58 \%)$ jika dibandingkan dengan insidens malaria di NTT tahun 2010 yaitu $14,9 \%$ dan sangat rendah dibandingkan dengan poin prevalensi pada Bulan Maret 2010 dari yaitu $28,2 \% .4,6$

Pengetahuan responden tentang penularan malaria yaitu $86 \%$ masyarakat mengetahui bahwa malaria di tularkan oleh gigitan nyamuk. Pengetahuan tentang dampak malaria jika tidak diobati yaitu $82,6 \%$ masyarakat mengatakan malaria bisa membunuh dan 96\% masyarakat mengetahui malaria dapat mengganggu pekerjaan. Distribusi pengetahuan masyarakat pada ketiga variabel pengetahuan tersebut relatif baik. Hasil penelitian ini sesuai dengan hasil penelitian yang dilakukan oleh Joseph et al, yang menyimpulkan bahwa masyarakat di Haiti mengetahui bahwa malaria adalah masalah umum yang terjadi di masyarakat dan mengetahui nyamuk adalah vektor penular malaria. ${ }^{6}$ Namun, pengetahuan responden tentang malaria tidak konsisten dengan perilaku mencegah gigitan nyamuk. Hal ini sesuai dengan hasil penelitian Sitorus tahun 2009 yang menyimpulkan bahwa perilaku tidak ada hubungan antara pengetahuan responden yang baik dengan praktek pencegahan malaria pada masyarakat suku anak dalam di Kabupaten Musi Banyuasin, dalam mencegah gigitan nyamuk masyarakat melakukannya dengan cara membakar dedaunan di sekitar rumah dan penggunaan kelambu yang jarang dimanfaatkan. ${ }^{7}$ Alasan yang disampaikan responden tidak menggunakan kelambu secara teratur adalah penggunaan kelambu merepotkan saat tidur, terkadang agak panas. Penggunaan kelambu saat tidur malam merupakan salah satu faktor risiko terjadinya malaria. ${ }^{8-10}$ Hasil penelitian ini sesuai dengan hasil penelitian Akal tahun 2006 yang menyimpulkan bahwa pengetahuan penduduk tentang malaria tidak berkorelasi dengan dengan kejadian malaria di Kabupaten Sumba Timur. ${ }^{11}$ Perilaku masyarakat dalam hal membakar dedauan untuk mengusir nyamuk didorong oleh alasan ekonomi dan kepraktisan. Alasan ekonomi yaitu memerlukan uang untuk membeli obat nyamuk bakar, sedangkan alasan kepraktisan karena di sekitar rumah banyak daduanan yang bisa dimanfaatkan.

Perilaku responden dalam hal mencari pengobatan yaitu membeli obat di kios-kios atau ke toko obat terdekat $(78,6 \%)$ terlebih dahulu kemudian ke fasilitas kesehatan kalau belum sembuh. Perilaku pencarian pengobatan tersebut relatif tidak baik. Namun demikian perilaku tersebut terbentuk karena adanya factor pendukung yaitu di kios-kios tertentu masih ditemukan obat cloroquin yang dari dulu digunakan oleh masyarkaat untuk mengobati malaria. Hasil penelitian ini sesuai dengan hasil penelitian Nuwaha yang menemukan bahwa di Uganda masyarakat melakukan pengobatansendiri jika terserang malaria, sebelum ke fasilitas kesehatan. ${ }^{12}$ Selain itu, hasil penelitian lain juga menunjukkan bahwa perilaku pengobatan yang tidak tepat merupakan faktor risiko terjadinya resistensi obat anti malaria. Sutanto menyimpulkan bahwa 56\% sampel resisten terhadap cloroquin di Kabupaten Alor NTT. Selain itu, Tarigan $30-100 \%$ plasmodium falciparum di Indonesia resisten dan di Thailand malaria resisten terhadap mefloquin (Wongsrichanalai et al, 2004). Selain itu, terdapat 34,3\% masyarakat menginginkan informasi tentang cara pengobatan malaria. Hal ini mengindikasikan bahwa konsep kuratif masih menjadi pilihan utama masyarakat dibandingkan dengan konsep promitif dan preventif sesuai visi Kementerian Kesehatan 2009 - 2013.13-17

Faktor lingkungan fisik meliputi beberapa variabel yaitu keberadaan tempat perindukan nyamuk pada jarak $<200$ meter dari rumah penduduk. Hasil penelitian menunjukkan jarak rumah dengan tempat perindukan nyamuk seperti sawah, dan lagoon merupakan faktor risiko penularan malaria karena jarak terbang nyamuk pada kondisi normal adalah maksimal 200 meter. Hal ini identik dengan studi yang telah dilakukan oleh Bhara, 2007 pada sejumlah daerah dengan tingkat endemisitas yang berbeda. ${ }^{11}$ Disimpulkan bahwa pada wilayah dengan tingkat endemisitas tinggi terhadap malaria lebih banyak responden tinggal dekat dengan tempat perindukan nyamuk yang berjarak kurang dari 200 meter dari rumah. Selain itu, 
hasil penelitian ini juga sesuai dengan hasil penelitian Harmendo, juga menyimpulkan bahwa ada hubungan antara faktor lingkungan (genangan air) dengan kejadian malaria. ${ }^{18}$ Selain itu, jenis atap rumah penderita malaria yang terbuat dari dedaunan juga merupakan faktor risiko adanya malaria. Atap rumah yang terbuat dari dedaunan menjadi tempat yang baik untuk bersembunyi nyamuk dalam rumah. Bhara, menyimpulkan rumah tempat tinggal penderita pada daerah endemisitas tinggi pada umumnya $70,5 \%$ berdinding bebak (pelepah lontar). ${ }^{11}$

Hasil analisis terhadap faktor lingkungan rumah tempat tinggal tersebut menunjukkan bahwa penyakit malaria erat kaitannya dengan kondisi sosial dan ekonomi masyarakat. Keadaan rumah yang berdinding bebak dan atap alang-alang mengindikasikan keadaan sosial ekonomi masyarakat yang menderita malaria yang masih rendah. Faktor sosial dan ekonomi seperti sanitasi yang buruk, perumahan, jenis pekerjaan, kemiskinan dan lain sebagainya mempunyai efek yang penting terhadap kejadian malaria terutama pada di negara-negara berkembang.

\section{Kesimpulan}

Faktor lingkungan rumah penderita malaria di Kecamatan Kupang Timut Kabupaten Kupang NTT lebih banyak terkait dengan konstruksi rumah dan keberadaan tempat perindukan nyamuk di sekitar rumah. Pengetahuan masyarakat tentang malaria, tidak konsisten dengan perilaku mencegah pencegahan malaria, perilaku pengobatan, dan perilaku pencarian pertolongan penyakit akibat malaria.

\section{Saran}

Upaya promotif dan preventif tentang malaria perlu terus ditingkatkan dalam rangka memutuskan mata rantai penularan malaria (environment). Penguatan sumber daya pada sektor kesehatan masyarakat terdepan (puskesmas pembantu, pondok bersalin desa, pos kesehatan desa, maupun puskesmas) perlu di tingkatkan terutama dalam mengampayekan upaya pencegahan atau pemberantasan malaria dengan baik dan benar di masyarakat.

\section{Daftar Pustaka}

1. World Health Organization (WHO). World malaria report [monograph on the internet]. Geneva: World Health Organization; 2008 [cited 2009 Oct 29]. Available from: http://www.who.int.

2. Hay SI, Guerra CA, Gething PW, Patil AP, Tatem AJ, Noor AM, et al. A world Malaria map: Plasmodium falciparum endemicity in 2007 [serial on the internet]. PLos Medicine. 2009; 6 (3) [cited 2009 Oct 10]. Available from: http://users.ox.ac.uk/ hay/107.pdf.

3. Snow RW, Guerra CA, Mutheu JJ, Hay SI. International funding for malaria control in relation to populations at risk of stable Plasmodium falciparum transmission [serial on the internet]. Plos Medicine 2008; 5 (7) [cited 2009 Oct 29]. Available from: http://users.ox.ac.uk/ hay/107.pdf.

4. Departemen Kesehatan Republik Indonesia. Laporan hasil Riset Kesehatan Dasar (Riskesdas) Nasional [monograph on the internet]. Jakarta: Badan Penelitian dan Pengembangan Kesehatan; 2007. Available from: www.litbangkes.go.id.

5. Dinas Kesehatan Provinsi Nusa Tenggara Timur Departemen Kesehatan Republik Indonesia. Laporan kasus malaria di Provinsi Nusa Tenggara Timur. Kupang: Dinas Kesehatan Provinsi Nusa Tenggara Timur Departemen Kesehatan Republik Indonesia; 2009.

6. Joseph K, Eisele TP, Benness A, Johnson D, Macintyre KA. Description of malaria-related knowledge, perception and practices in the Artibonite Valey of Haiti: implications for malaria Control [serial on the internet]. Am Trop Med Hyg. 78 (2); 2008: 262-9 [cited 2010 Aug 5]. Available from: www.theamericansocietyoftropicalmedicineadnhygiene.

7. Hotnida S, Ambarita LP. Pengetahuan, sikap dan perilaku masyarakat desa Pagar terhadap malaria (pemukiman Suku Anak Dalam) Kabupaten Musi Banyuasin. Diunduh dari: www.LitbangkemenkesRI.

8. Chwatt B. Essential malariology. $2^{\text {nd }}$ ed. New York: A Willey medical Publication; 1985.

9. World Health Organization. Manual on practical entomology in malaria; part II. Geneva: World Health Organization Offset Publication; 1995.

10. Bau SH. Perilaku istirahat nyamuk Anopheles sp. di Kota Kupang. Laporan Karya Tulis Ilmiah Polteknik Kesehatan Departemen Kesehatan Kupang. Kupang: Polteknik Kesehatan Departemen Kesehatan Kupang; 2009.

11. Bhara AR. Studi perilaku nyamuk Anopheles sp. di Kelurahan Airmata Kecamatan Oebobo Kota Kupang. Laporan Karya Tulis Ilmiah Polteknik Kesehatan Departemen Kesehatan Kupang. Kupang: Polteknik Kesehatan Departemen Kesehatan Kupang; 2009.

12. Nuwaha, Fred. People's perception of Malaria in Mbarara, Uganda. Trop Med Int Health [serial on the internet]. 2003; 5: $462-70$ [cited 2012 Dec 15]. Available from: www.tropicalmedicine.

13. Sutanto I, Suprijanto S, Nurhayati, Manoempil P, Baird JK. Resistance to chloroquine by Plasmodium vivax at Alor in the Lesser Sundas Archipelago in eastern Indonesia. American Journal of Tropical Medicine and Hygiene [serial on the internet]. 2009; 81 (2): 338-42 [cited 2010 oct 16]. Available from: http://www.ncbi.nlm.nih.gov/pubmed/.

14. Tarigan J. Kombinasi kina tetrasiklin pada pengobatan Malaria falciparum tanpa komplikasi di daerah resisten multidrug malaria [diakses tanggal 2009 Oct 15]. Diunduh dari: http://library.usu.ac.id/download/fk/penydalam-jerahim.

15. Angel D, Manuel WH, Dominic G, Flora K, Christian L, Iddy M, et al. Socio-cultural factors explaining timely and appropriate use of health facilities for degedege in south-eastern Tanzania. Malaria J [ serial on the internet]. 2009; 8:144 [cited 2010 Aug 20]. Available 
from: http://www.malariajournal.com/content.

16. Chansuda W, Somsak P, Meshnick S, Shanks GD, Krongthong T. Mefloquine-its 20 Years in The Thai Malaria Control Program. The Southeast Asian Journal of Tropical Medicine and Public Health. 2004; 35 (2): 300-8.

17. Kementerian Kesehatan Republik Indonesia. Rencana Strategis
Kementerian Kesehatan Republik Indonesia. Jakarta: Kementerian Kesehatan Republik Indonesia; 2009.

18. Hermendo, Wahyuningsih NE, Raharjo M. Faktor risiko kejadian malaria di wilayah kerja puskesmas kenanga Kecamatan Sungailiat kabupaten Bangka Provinsi Kepulauan Bangka Belitung. Jurnal Kesehatan Lingkungan Indonesia. 2009; 9 (1): 1-4. 